\title{
28 Research Square \\ Strontium as a Tracer for Calcium: Uptake, Transport and Partitioning Within Tomato Plants
}

Petar Jovanović

Shimon Rachmilevitch

Noam Roitman

Ran Erel ( $\square$ ran.erel@mail.huji.ac.il)

Gilat Research Center, Agricultural Research Organization https://orcid.org/0000-0003-1780-3291

\section{Research Article}

Keywords: calcium, strontium, tomato, tracer, blossom end rot (BER).

Posted Date: March 16th, 2021

DOI: https://doi.org/10.21203/rs.3.rs-307555/v1

License: (c) (i) This work is licensed under a Creative Commons Attribution 4.0 International License.

Read Full License

Version of Record: A version of this preprint was published at Plant and Soil on July 1st, 2021. See the published version at https://doi.org/10.1007/s11104-021-05024-6. 


\section{Abstract}

\section{Purpose}

Calcium $\left(\mathrm{Ca}^{2+}\right)$ is a major structural plant nutrient whose low mobility in the phloem causes deleterious nutritional disorders in non-transpiring organs. Since strontium $\left(\mathrm{Sr}^{2+}\right)$ and $\mathrm{Ca}^{2+}$ share many chemical properties, $\mathrm{Sr}^{2+}$ is frequently used as a tracer to study $\mathrm{Ca}^{2+}$ cycles in ecosystems. However, the level of agreement between $\mathrm{Sr}^{2+}$ and $\mathrm{Ca}^{2+}$ distribution pattern in plants is debatable, and several studies have reported toxic effects of $\mathrm{Sr}^{2+}$. Therefore, we investigated $\mathrm{Sr}^{2+}$ and $\mathrm{Ca}^{2+}$ uptake rates and distribution pattern to determine how reliably $\mathrm{Sr}^{2+}$ can be used as a tracer of $\mathrm{Ca}^{2+}$ in tomato plants (Solanum lycopersicum L.).

\section{Methods}

We conducted six independent experiments of various duration: from a few hours to several weeks, in hydroponic and perlite substrate. We treated plants with either $\mathrm{Ca}^{2+} \mathrm{or} \mathrm{Sr}^{2+}$ at equivalent concentrations and monitored their accumulation in shoot and fruits.

\section{Results}

Under short-term exposure (hours), $\mathrm{Ca}^{2+}$ and $\mathrm{Sr}^{2+}$ uptake and distribution within the plant were comparable, while the long-term exposure (days and weeks) to $4 \mathrm{mMSr}^{2+}$ reduced transpiration and biomass accumulation. The toxic effect of $\mathrm{Sr}^{2+}$ was more prominent when growth conditions were favourable. Nonetheless, $\mathrm{Sr}^{2+}$ accumulated similarly to $\mathrm{Ca}^{2+}$ in shoot and fruit. Surprisingly, $\mathrm{Sr}^{2+}$ deposition in tomato fruit cell walls prevented blossom end rot (BER) to the same degree as $\mathrm{Ca}^{2+}$.

\section{Conclusion}

$\mathrm{Sr}^{2+}$ can credibly be used as a tracer of $\mathrm{Ca}^{2+}$ uptake and allocation in the short-term, making $\mathrm{Sr}^{2+} \mathrm{a}$ powerful tool to study the factors governing $\mathrm{Ca}^{2+}$ allocation to plant organs, primarily fruit $\mathrm{Ca}^{2+}$ delivery.

\section{Introduction}

Calcium (Ca) is an essential macronutrient for plants with vital structural, metabolic and signalling roles (Thor 2019). Ca has a role in stomatal movement, intracellular signal transduction, cell wall integrity (strength and elasticity), stress amelioration and resistance to fruit disease and disorders (White and Broadley 2003; Hocking et al. 2016; Parvin et al. 2019; Thor 2019). Ca is mainly present in the soil solution as a cation $\left(\mathrm{Ca}^{2+}\right)$ originating mainly from mineral weathering release and atmospheric deposition (Drouet et al. 2005; Marschner 2011). $\mathrm{Ca}^{2+}$ enters the plant root system mostly with the water mass flow, moving via symplast or apoplast (Gilliham et al. 2011). The symplastic pathway is mainly used for short-distance $\mathrm{Ca}^{2+}$ delivery to the cells for the purpose of nutrition (metabolism s.str.) and 
signalling; in contrast, the apoplastic pathway (which is significantly dependent on transpiration rate) is primarily used for long-distance $\mathrm{Ca}^{2+}$ translocation into highly transpiring organs via xylem (GonzálezFontes et al. 2017). Transpiring organs tend to accumulate high $\mathrm{Ca}^{2+}$ levels while non-transpiring organs like fruits and tubers tend to have low $\mathrm{Ca}^{2+}$ concentration (Gilliham et al., 2011; Kumar et al., 2015; González-Fontes et al., 2017). When inside highly transpiring organs, $\mathrm{Ca}^{2+}$ is taken up by the cells and deposited inside vacuoles or sequestrated into leaf-trichomes, which imposes $\mathrm{Ca}^{2+}$ phloem immobility (White, 2001; Gilliham et al., 2011; Kumar et al., 2015).

The function of $\mathrm{Ca}^{2+}$ in plants can be crudely divided into two groups: "nutritional (structural)" and "signalling". Depending on the function, $\mathrm{Ca}^{2+}$ uptake and transport across plant biological membranes can be passive, mediated by non-selective ion channels, or active, mediated by $\mathrm{Ca}^{2+-}$ ATP-ases and $\mathrm{Ca}^{2+} / \mathrm{H}^{+}$exchangers (White and Broadley 2003; Demidchik et al. 2018; Thor 2019). Moreover, pathways of $\mathrm{Ca}^{2+}$ uptake and transport in plants, to the large degree, are not specific only to $\mathrm{Ca}^{2+}$; mono- and divalent cations (e.g. $\mathrm{Mg}^{2+}, \mathrm{Rb}^{+}, \mathrm{Sr}^{2+}$ and $\mathrm{Ba}^{2+}$ ) can also utilise these pathways (White and Broadley 2003; Moyen and Roblin 2010; Demidchik et al. 2018). Commonly used blockers of these pathways, at the root cell membrane level, are lanthanides $\left(\mathrm{Gd}^{3+}\right.$ and $\left.\mathrm{La}^{3+}\right)$, dihydropyridines and phenylalkylamines (Demidchik et al., 2002, 2018; Achary et al., 2013).

$\mathrm{Ca}^{2+}$ cross-links with pectin residues in the cell wall and modifies the activity and expression of various cell wall enzymes, strongly determining the physical and structural properties of fruits (de Freitas et al. 2012a; Martins et al. 2018). Unobstructed $\mathrm{Ca}^{2+}$ delivery is a prerequisite for normal fruit development and stress amelioration (Hocking et al. 2016; Parvin et al. 2019). Insufficient $\mathrm{Ca}^{2+}$ supply may cause membrane and cell wall breakdown, leading to the onset of various physiological disorders and shorter shelf life (Gerasopoulos and Drogoudi, 2005; de Freitas et al., 2012). The most widely recognised $\mathrm{Ca}^{2+}$ related disorders are blossom end rot (BER) in bell peppers and tomato (Hagassou et al., 2019; MayorgaGómez et al., 2020), bitter pit in apples (de Freitas et al. 2010) or internal rust in potato (Palta 2010). BER is a widespread disorder in tomato production, causing substantial economic damage. Symptoms typically include the development of the dark spot at the distal part of the tomato fruit (Taylor and Locascio 2004; Ho and White 2005; Hagassou et al. 2019).

Strontium (Sr) is an alkaline earth metal that is mainly found as an oxide in the Earth's crust, released as an ion $\left(\mathrm{Sr}^{2+}\right)$ during weathering of rocks or originating from anthropogenic sources. $\mathrm{Sr}^{2+}$ is typically found at low environmental concentration compared to $\mathrm{Ca}^{2+}$ (370 vs 36,500 ppm, in the soil) (Lide 2005; Burger and Lichtscheidl 2019). Four stable isotopes of $\mathrm{Sr}^{2+}$, have been identified: ${ }^{84} \mathrm{Sr}, 0.56 \% ;{ }^{86} \mathrm{Sr}, 9.87 \%$; ${ }^{87} \mathrm{Sr}, 7.04 \%$; and ${ }^{88} \mathrm{Sr}, 82.53 \%$ (Capo et al. 1998). The increased cycling of radio and stable $\mathrm{Sr}^{2+}$ isotopes through the biosphere via trophic chains in the last 50 years led to an increase in the number of scientific studies on the biological effect of $\mathrm{Sr}^{2+}$ (Gould et al. 2000). Some of these studies have shown that plants (e.g. sunflower) do not differentiate between the uptake of radioactive and stable strontium isotopes (Soudek et al. 2006). 
The effect of $\mathrm{Sr}^{2+}$ on plants varies from a negative impact on the growth, photosynthesis, genetic material to a positive impact on the increase in the production of secondary metabolites and alleviation of calcium deficiency (depending on the plant taxonomy and growth conditions) (Burger and Lichtscheidl 2019). Starting at low concentrations (about one $m M$, depending on the plant species and growing conditions), $\mathrm{Sr}^{2+}$ may exhibit a toxic effect on plants, reduction of plant biomass, chromosomal abnormalities and the destruction of the photosynthetic apparatus (Seregin and Kozhevnikova 2004; Kanter et al. 2010; Burger et al. 2019a, b).

Numerous studies have reported that $\mathrm{Ca}^{2+}$ and $\mathrm{Sr}^{2+}$ behave very similarly in the biosphere (Pett-Ridge et al., 2009) and lithosphere where $\mathrm{Sr}^{2+}$ can substitute $\mathrm{Ca}^{2+}$ in various minerals, including gypsum, calcite and dolomite (Coelho et al., 2017) due to similar physicochemical characteristics. The inability of plants to discriminate between these two elements has been shown in the soil of the forest ecosystems, inside plants organs of 138 plant families (Watanabe et al. 2007; Drouet and Herbauts 2008; Burger et al. 2019b) and in the field crop species of different families (Watanabe et al. 2016). It is interesting to note that several Arabidopsis accessions can discriminate between $\mathrm{Ca}^{2+}$ and $\mathrm{Sr}^{2+}$ in the growth medium (Kanter et al. 2010) and that $\mathrm{Ca}^{2+}$ concentration in the medium governs the process of discrimination.

Natural $\mathrm{Sr}^{2+}$ isotopes are increasingly used as tracers of $\mathrm{Ca}^{2+}$ in land and water ecosystems, mainly to characterise and monitor $\mathrm{Ca}^{2+}$ cycles in the biosphere and lithosphere (Åberg et al. 1990; Drouet et al. 2005; Drouet and Herbauts 2008; Peek and Clementz 2012). Moreover, $\mathrm{Sr}^{2+}$ is also used as a tracer of $\mathrm{Ca}^{2+}$ uptake and its symplastic and apoplastic transport to various plant organs: to fruits, fruit pedicel and leaves (Storey and Leigh 2004; Song et al. 2018; Rosen et al. 2019); to roots (McGonigle and Grant 2015) and embryos during development (Laszlo 1994). Some studies have established the direct connection between $\mathrm{Ca}^{2+}$ and $\mathrm{Sr}^{2+}$ allocation to the level of cell types (Storey and Leigh 2004), while others assumed that $\mathrm{Ca}^{2+}$ and $\mathrm{Sr}^{2+}$ share transport and distribution pattern without validation (Song et al. 2018; Rosen et al. 2019). However, the level of agreement between uptake and distribution of $\mathrm{Sr}^{2+}$ and $\mathrm{Ca}^{2+}$ in plants is debatable. The physiological segregation of $\mathrm{Sr}^{2+}$ relative to $\mathrm{Ca}^{2+}$ does occur (Dasch et al. 2006; Watanabe et al. 2016), and several studies have reported toxic effects of $\mathrm{Sr}^{2+}$ (Burger et al. 2019a). Moreover, tissue and cellular distribution patterns of different ions can be linked to many processes, including plants' mechanisms to withstand abiotic stresses (Pongrac et al. 2013), which possibly can be an additional source of differences between $\mathrm{Ca}^{2+}$ and $\mathrm{Sr}^{2+}$ plant uptake and distribution.

With this in mind, the potential of utilising $\mathrm{Sr}^{2+}$ as a tracer of $\mathrm{Ca}^{2+}$ uptake and transport is not yet well understood. The $\mathrm{Sr}^{2+}$ uptake and transport require more attention, especially considering the toxic effects of $\mathrm{Sr}^{2+}$ on plants related to the experimental conditions, duration of exposure and $\mathrm{Sr}^{2+}$ concentrations. Furthermore, the degree of similarity between $\mathrm{Ca}^{2+}$ and $\mathrm{Sr}^{2+}$ related to partitioning within different plant organs (e.g. fruits and leaves) of different plant species, under different environmental conditions and the possible physiological role of $\mathrm{Sr}^{2+}$ are not that well established (Dasch et al. 2006; Watanabe et al. 2016). The current study's objective was to evaluate the feasibly of using a stable isotope of $\mathrm{Sr}^{2+}\left({ }^{8} \mathrm{Sr}\right.$ as $\left.\mathrm{SrCl}_{2}\right)$ 
as a short and long-term tracer for $\mathrm{Ca}^{2+}$ uptake and distribution within tomato plants and to assess $\mathrm{Sr}^{2+}$ toxicity as affected by the duration of the exposure. The utilisation of non-radioactive $\mathrm{Sr}^{2+}$ isotopes to monitor $\mathrm{Ca}^{2+}$ transport may provide us with a simple but powerful tool for studying environmental factors determining $\mathrm{Ca}^{2+}$ allocation to different plant organs and, specifically, fruits.

\section{Materials And Methods}

We have conducted six independent experiments on tomato plants (Solanum lycopersicum L. var. Brigade, Hishtil Nursery, Israel): four long-term experiments conducted in perlite and two short-term experiments conducted in hydroponics (Table 1). In all experiments, plants were treated with $\mathrm{Ca}^{2+} \mathrm{or} \mathrm{Sr}^{2+}$, separately, to avoid the interaction of these two elements at the plant cell membrane (Moyen and Roblin 2013).

\section{Long-term $\mathrm{Sr}^{2+}$ exposure experiments}

Four independent long-term experiments were conducted at various environmental conditions detailed in Table 1 (Exp 1-4). Tomato plants were grown in soilless culture using perlite substrate with a particle size of 0.075-1.5 mm (Agrikal, Israel). Plants were grown in net house or greenhouse at the Gilat Research Centre, southern Israel $\left(31^{\circ} 21^{\prime} \mathrm{N}, 34^{\circ} 42^{\prime} \mathrm{E}\right)$. Plants were irrigated at excess three times a day with an irrigation solution containing $100 \mathrm{mg} \mathrm{I}^{-1} \mathrm{~N}^{-N_{3}}, 10 \mathrm{mg} \mathrm{I}^{-1} \mathrm{~N}_{3} \mathrm{NH}_{4}, 5 \mathrm{mg} \mathrm{I}^{-1} \mathrm{P}, 80 \mathrm{mg} \mathrm{I}^{-1} \mathrm{~K}, 15 \mathrm{mg} \mathrm{l}^{-1} \mathrm{Mg}$, and $35 \mathrm{mg} \mathrm{I}^{-1} \mathrm{Ca}$. Microelements were supplied by liquid chelated solution (Koratin, Deshanim, Israel). Five to six weeks after planting, when plants had four to five fruitlets, three treatments were applied: $\mathrm{Ca}^{2+}$ nutrition ("+Ca"); $\mathrm{Sr}^{2+}$ nutrition ("+Sr") and no $\mathrm{Ca}^{2+}$ and no $\mathrm{Sr}^{2+}$ ("-Ca/-Sr"), (Table 1. Exp. 1-4). The remaining nutrients and irrigation pattern remained the same for all treatments. Plants were treated for 24 to 40 days. At the end of the experiments, the plants were harvested, and shoot and fruit biomass was determined. The development of blossom end rot (BER) quantified by visually observing and counting the dark spot symptoms developed on and inside each tomato fruit. All plant material was oven-dried on $70^{\circ} \mathrm{C}$ for a minimum of 72 hours, ball grounded (Mixer Mill MM 400, Retsch GmbH, Germany), digested using a microwave digestion system (MARS 6, CEM Corporation, USA) and analysed for mineral concentration using ICP-OES (ICP-OES 5100, Agilent Technologies Inc., USA). For simplicity, the results of a single representative trial (Exp. 4) are presented in Fig. 3. The remaining trials are shown in Fig S1, S2 and S3.

\section{Gas exchange measurement}

In Exp. 3 and Exp. 4, the stomatal conductance to $\mathrm{H}_{2} \mathrm{O}\left(\mathrm{g}_{\mathrm{s}}\right)$ and photosynthetic rate (A) of fully expanded leaves were measured using the CIRAS-III portable photosynthesis system (PP Systems, USA) on the first, second and ninth day after starting the treatment. The CIRAS-III system was equipped with a modular LED chamber head, set to the photosynthetic photon flux density of $1,000 \mu \mathrm{mol}$ photons $\mathrm{m}^{-2} \mathrm{~s}^{-1}$, with 
the reference $\mathrm{CO}_{2}$ concentration of $400 \mathrm{umol} \mathrm{mol}^{-1}$, and leaf temperature of $25^{\circ} \mathrm{C}$. Measurements were taken on the morning of a clear day (between 8:00 $\mathrm{h}$ and 10:00 h).

\section{Scanning electron microscopy of the fruits}

Intact tomato fruits from Exp. 4 (Table 1) were kept at $4^{\circ} \mathrm{C}$ in $70 \%$ ethanol until further processing. Before the scanning, freehand sections of the outer pericarp containing epidermis and vascular bundles were made using a razor blade, six sections per treatment. The sections were rehydrated two times for 10 minutes in double-distilled water and placed inside the microscope's low vacuum chamber. A scanning electron microscope (SEM, VEGA3, Tescan, Czech Republic) equipped with EDS (Energy-dispersive X-ray spectroscopy) detector (model X-act, Oxford Instruments, UK) was used for scanning as described in Tan et al. (2020). Briefly, the SEM's acceleration potential was set to $30 \mathrm{kV}$, working distance to $15 \mathrm{~mm}$, beam intensity to 15 , chamber pressure to $10 \mathrm{~Pa}$ and the spot size to $230 \mathrm{~nm}$. On the EDS, the following elements were selected for scanning: $\mathrm{C}, \mathrm{O}, \mathrm{Na}, \mathrm{Mg}, \mathrm{P}, \mathrm{K}, \mathrm{Ca}$ and $\mathrm{Sr}$, while the processing time was set to level 5 (out of 6 levels offered in the software). A representative fruit tissue scan is presented in Fig. 1. Ca and $\mathrm{Sr}$ results were averaged for four separate scanning points and expressed as weight percentages of total analysed elements.

\section{Short-term $\mathrm{Sr}^{2+}$ exposure experiments}

Two short-term $\mathrm{Sr}^{2+}$ exposure experiments (Table 1, Exp. 5-6) were conducted on tomato plants in a hydroponics system. Plants were grown in a 1:1,000 solution of the commercial 5-3-8 NPK fertiliser solution (Shefert, Deshanim, Israel) for two weeks (first flowers).

\section{Diurnal nutrients uptake}

Exp. 5 was conducted in a greenhouse to describe the diurnal uptake rate of $\mathrm{Ca}^{2+}$ and $\mathrm{Sr}^{2+}$. Plants were washed in distilled water and separated into two groups $(n=4)$ and exposed to either: $4 \mathrm{mMCa}^{2+}$ or $\mathrm{Sr}^{2+}$

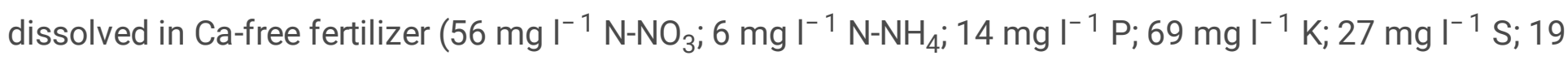
$\mathrm{mg} \mathrm{I}^{-1} \mathrm{Mg} ; 76 \mathrm{mg} \mathrm{I}^{-1} \mathrm{Cl} ; 50 \mathrm{mg} \mathrm{I}^{-1} \mathrm{Na} ; 1.2 \mathrm{mg} \mathrm{l}^{-1} \mathrm{Fe} ; \mathrm{pH}=7.2-7.8, \mathrm{EC}=660-731 \mu \mathrm{S}$ ).

The exposure lasted for 20.5 hours ( 8.5 hours of the night and 12 hours of daylight). The "nutrient depletion" method was used to determine the diurnal uptake rate of $\mathrm{Sr}^{2+}$ and $\mathrm{Ca}^{2+}$, using the elements' mass in the solution (at the beginning and the end of the exposure), the element's molar weight and the duration of the uptake. The nutrient solution sampling was done every three hours. The "nutrient depletion" method was verified by conducting destructive tissue analysis (Fig. 2).

Uptake $\left(\right.$ mmol h $\left.^{-1}\right)=\frac{\left[\frac{\left(C_{1} \times V_{1}\right)-\left(C_{2} \times V_{2}\right)}{M W}\right] \times 1000}{\text { Duration of the uptake }(\mathrm{hr})}$

$\mathrm{C}_{1}$ - element's concentration at the beginning of the exposure $\left(\mathrm{mg} \mathrm{L}^{-1}\right)$ 
$\mathrm{C}_{2}$ - element's concentration at the end of the exposure $\left(\mathrm{mg} \mathrm{L}^{-1}\right)$

$V_{1}$ - the volume of the solution at the beginning of the exposure $(L)$

$V_{2}$ - the volume of the solution at the end of the exposure $(\mathrm{L})$

$\mathrm{MW}$ - the molar weight of the element $\left(\mathrm{g} \mathrm{mol}^{-1}\right)$

\section{$\mathrm{Ca}^{2+} / \mathrm{Sr}^{2+}$ blockers}

Exp. 6 was conducted in a 3.7 by $6.1 \mathrm{~m}$ growth room equipped with a ventilator, AC, humidifier and dehumidifier connected to a controller. Photosynthetic light (Solar system 550, California lightworks, US) conditions were: $12 \mathrm{~h}$ light / dark and light intensity of $680 \mu \mathrm{E} \mathrm{m}^{-2} \mathrm{~s}^{-1}$. Following two weeks of growth, roots were washed in distilled water and plants were divided into three groups ("No blockers", "Lanthanum" and "Gadolinium", $\mathrm{n}=8$ ), each with two sub-groups ("Ca" and "Sr", $\mathrm{n}=4$ ), and treated for four hours (distilled water; $4 \mathrm{mMLaCl}_{3}$ and $4 \mathrm{mM} \mathrm{GdCl}_{3} ; 4 \mathrm{mM} \mathrm{CaCl}_{2}$ and $4 \mathrm{mM} \mathrm{SrCl}$, respectively).

The "nutrient depletion" method was used to determine the uptake rate of $\mathrm{Sr}^{2+}$ and $\mathrm{Ca}^{2+}$, using the elements' mass in the solution (at the beginning and the end), duration of the uptake, and roots' surface area. The elemental analysis of the solution and the plant material was done using ICP-OES (ICP-OES 5100, Agilent Technologies Inc., USA). Root surface area was measured by digital images on a flat-bed scanner (Expression 11000XL, Epson, Japan) and analysed using WinRhizo software (WinRhizo 2016a, Regent Instruments Inc. Canada). Water uptake was measured by recording the solution's mass at the beginning and the end of the experiment. 
Table 1

Description of all the $\mathrm{Sr}^{2+}$ exposure experiments conducted at Gilat

\begin{tabular}{|c|c|c|c|c|c|c|}
\hline $\begin{array}{l}\text { Exp. } \\
\text { \# }\end{array}$ & $\begin{array}{l}\text { Time frame of the whole } \\
\text { experiment }\end{array}$ & Treatment $^{\mathrm{a}, \mathrm{b}}$ & $\begin{array}{l}\text { Length } \\
\text { of the } \\
\text { treatment }\end{array}$ & $\begin{array}{l}\text { Temperature } \\
\text { during the } \\
\text { exposure }\end{array}$ & $\begin{array}{l}\text { Humidity } \\
\text { during the } \\
\text { exposure }\end{array}$ & $\mathrm{n}$ \\
\hline 1. & $\begin{array}{l}\text { September-December } \\
\text { 2016; greenhouse, perlite }\end{array}$ & $\begin{array}{l}+\mathrm{Ca}(1 \mathrm{mM} \\
\left.\mathrm{CaCl}_{2}\right) \\
+\mathrm{Sr}(1 \mathrm{mM} \\
\left.\mathrm{SrCl}_{2}\right) \\
-\mathrm{Ca} /-\mathrm{Sr} \\
\text { (No Ca and } \\
\text { no Sr) }\end{array}$ & 40 days & $\begin{array}{l}\text { Max: } 30^{\circ} \mathrm{C} \\
\text { Min: } 7^{\circ} \mathrm{C} \\
\text { Average: } \\
18^{\circ} \mathrm{C}\end{array}$ & ND & 5 \\
\hline 2. & $\begin{array}{l}\text { July-October } \\
\text { 2017; greenhouse } \\
\text { perlite }\end{array}$ & $\begin{array}{l}+\mathrm{Ca}(2 \mathrm{mM} \\
\left.\mathrm{CaCl}_{2}\right) \\
+\mathrm{Sr}(2 \mathrm{mM} \\
\left.\mathrm{SrCl}_{2}\right) \\
-\mathrm{Ca} /-\mathrm{Sr} \\
\text { (No } \mathrm{Ca} \text { and } \\
\text { no Sr) }\end{array}$ & 26 days & $\begin{array}{l}\text { Max: } 31^{\circ} \mathrm{C} \\
\text { Min: } 16^{\circ} \mathrm{C} \\
\text { Average: } \\
23^{\circ} \mathrm{C}\end{array}$ & ND & 5 \\
\hline 3. & $\begin{array}{l}\text { June-September } \\
\text { 2018; net-house } \\
\text { perlite }\end{array}$ & $\begin{array}{l}+\mathrm{Ca}(4 \mathrm{mM} \\
\left.\mathrm{CaCl}_{2}\right) \\
+\mathrm{Sr}(4 \mathrm{mM} \\
\left.\mathrm{SrCl}_{2}\right) \\
-\mathrm{Ca} /-\mathrm{Sr} \\
\text { (No Ca and } \\
\text { no Sr) }\end{array}$ & 29 days & $\begin{array}{l}\text { Max: } 42^{\circ} \mathrm{C} \\
\text { Min: } 20^{\circ} \mathrm{C} \\
\text { Average: } \\
28^{\circ} \mathrm{C}\end{array}$ & $\begin{array}{l}\text { Max: } 90 \% \\
\text { Min: } 31 \% \\
\text { Average:66\% }\end{array}$ & 5 \\
\hline $4 .^{c}$ & $\begin{array}{l}\text { October-January } \\
\text { 2018-2019; net-house } \\
\text { perlite }\end{array}$ & $\begin{array}{l}+\mathrm{Ca}(4 \mathrm{mM} \\
\left.\mathrm{CaCl}_{2}\right) \\
+\mathrm{Sr}(4 \mathrm{mM} \\
\left.\mathrm{SrCl}_{2}\right) \\
-\mathrm{Ca} /-\mathrm{Sr} \\
\text { (No Ca and } \\
\text { no Sr) }\end{array}$ & 24 days & $\begin{array}{l}\text { Max: } 28^{\circ} \mathrm{C} \\
\text { Min: } 6^{\circ} \mathrm{C} \\
\text { Average: } \\
14^{\circ} \mathrm{C}\end{array}$ & $\begin{array}{l}\text { Max: } 94 \% \\
\text { Min: } 30 \% \\
\text { Average:70\% }\end{array}$ & 8 \\
\hline
\end{tabular}




\begin{tabular}{|c|c|c|c|c|c|c|}
\hline $\begin{array}{l}\text { Exp. } \\
\#\end{array}$ & $\begin{array}{l}\text { Time frame of the whole } \\
\text { experiment }\end{array}$ & Treatment ${ }^{a, b}$ & $\begin{array}{l}\text { Length } \\
\text { of the } \\
\text { treatment }\end{array}$ & $\begin{array}{l}\text { Temperature } \\
\text { during the } \\
\text { exposure }\end{array}$ & $\begin{array}{l}\text { Humidity } \\
\text { during the } \\
\text { exposure }\end{array}$ & $\mathrm{n}$ \\
\hline 5. & $\begin{array}{l}\text { July } 2019 \\
\text { greenhouse } \\
\text { hydroponics }\end{array}$ & $\begin{array}{l}+\mathrm{Ca}(4 \mathrm{mM} \\
\left.\mathrm{CaCl}_{2}\right) \\
+\mathrm{Sr}(4 \mathrm{mM} \\
\left.\mathrm{CaCl}_{2}\right)\end{array}$ & 20.5 hours & $\begin{array}{l}\text { Day: } 33^{\circ} \mathrm{C} \\
\text { Night: } 23^{\circ} \mathrm{C}\end{array}$ & $\begin{array}{l}\text { Day: } 54 \% \text {, } \\
\text { Night: } 84 \%\end{array}$ & 4 \\
\hline 6. & $\begin{array}{l}\text { July } 2020 \text {, growth room, } \\
\text { hydroponics } \\
\text { Night } 12 \mathrm{~h} / \text { Day } 12 \mathrm{~h}\end{array}$ & 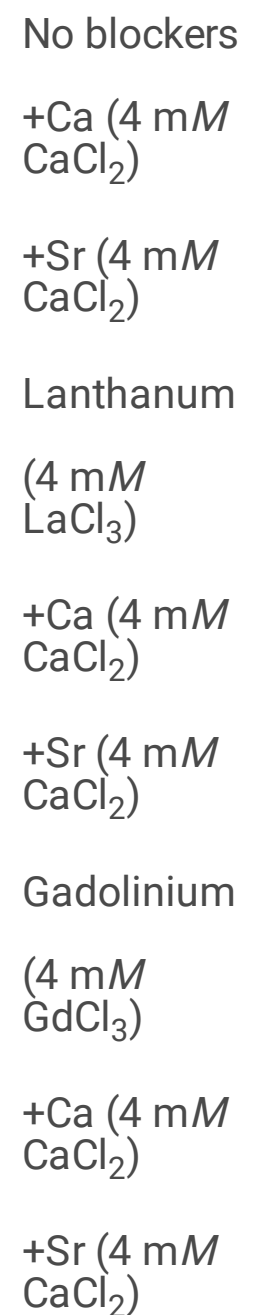 & 4 hours & $\begin{array}{l}\text { Day: } 25^{\circ} \mathrm{C} \\
\text { Night: } 21^{\circ} \mathrm{C}\end{array}$ & $\begin{array}{l}\text { Day: } 65 \% \\
\text { Night: } 83 \%\end{array}$ & 8 \\
\hline
\end{tabular}

a Background for all treatments in the Exp. 1-4 is Ca-free fertilizer: $100 \mathrm{mg} \mathrm{I}^{-1} \mathrm{~N}^{-\mathrm{NO}_{3}}, 10 \mathrm{mg} \mathrm{I}^{-1} \mathrm{~N}-\mathrm{NH}_{4}, 5$ $\mathrm{mg} \mathrm{l}^{-1} \mathrm{P}, 80 \mathrm{mg} \mathrm{I}^{-1} \mathrm{~K}, 15 \mathrm{mg} \mathrm{I}^{-1} \mathrm{Mg}+$ liquid chelated microelement solution.

${ }^{\mathbf{b}}$ Background for all treatments in the Exp. 5 is Ca-free fertilizer: $56 \mathrm{mg} \mathrm{I}^{-1} \mathrm{~N}-\mathrm{NO}_{3} ; 6 \mathrm{mg} \mathrm{I}^{-1} \mathrm{~N}^{-\mathrm{NH}_{4}} ; 14 \mathrm{mg}$ $\mathrm{I}^{-1} \mathrm{P} ; 69 \mathrm{mg} \mathrm{I}^{-1} \mathrm{~K} ; 27 \mathrm{mg} \mathrm{I}^{-1} \mathrm{~S} ; 19 \mathrm{mg} \mathrm{I^{-1 }} \mathrm{Mg} ; 76 \mathrm{mg} \mathrm{I}^{-1} \mathrm{Cl} ; 50 \mathrm{mg} \mathrm{I}^{-1} \mathrm{Na} ; 1.2 \mathrm{mg} \mathrm{I}^{-1} \mathrm{Fe} ; \mathrm{pH}=7.2-7.8, \mathrm{EC}$ $=660-731 \mu \mathrm{S}$.

${ }^{\mathbf{c}}$ Representative trial 


\section{Statistical analyses}

All experiments' setup was a complete randomisation design; the number of replicates is indicated next to each experiment in Table 1. Statistical analysis was done by JMP 14 software (JMP, SAS Institute, USA). The linear regression was fitted and tested to the correlation between $\mathrm{Sr}^{2+}$ uptake by "solution depletion" versus tissue analysis. The results of the remaining experiments were averaged, tested by ANOVA. If the treatment effect was significant, groups were compared using Tukey's HSD-test. Results were plotted on graphs together with standard errors, generated using GraphPad Prism 6 (GraphPad Software, Inc. USA).

\section{Results}

\section{Long-term response to strontium}

Following 24 days exposure to $4 \mathrm{mM} \mathrm{CaCl}_{2}, 4 \mathrm{mMSrCl}$ or Ca-free fertiliser (Exp. 4, Table 1.) (labelled as "+Ca", "+Sr" and "-Ca/-Sr" respectively, Fig. 3), fruit number (not shown) and plant biomass (shoot + fruit) was not significantly influenced by the treatment (Fig. 3a). The percentage of fruit with visual external and internal symptoms of BER was markedly high in "-Ca/-Sr" plants (44\%), lower in "+Ca" (18\%) and lowest in the "Sr" (11\%) (Fig. 3b). We saw comparable results in Exp. 1, 2 and 3 (Fig S1, S2 and S3). The concentration of $\mathrm{Ca}^{2+}$ in the shoot was the highest in the " $+\mathrm{Ca}$ " group, while there was no difference between the two other groups (Fig. 3c). The $\mathrm{Ca}^{2+}$ concentration in the fruit was the highest in the "+Ca" group, lower in "+Sr" and the lowest in the "-Ca/-Sr" (Fig. 3d). $\mathrm{Sr}^{2+}$ was only detectable in the group treated with $\mathrm{SrCl}_{2}$. Moreover, the combined $\mathrm{Ca}^{2+}$ and $\mathrm{Sr}^{2+}$ concentration in the group "+Sr" was at a similar level as $\mathrm{Ca}^{2+}$ concentration in the group "+Ca" (fruits: $\mathrm{Ca}^{2+}+\mathrm{Sr}^{2+}=0.038 \mathrm{~mol} \mathrm{~kg}^{-1}$ while $\mathrm{Ca}^{2+}$ $=0.036 \mathrm{~mol} \mathrm{~kg}^{-1}$ ) (Fig. 3c, d). We also saw comparable results in Exp. 1, 2 and 3 (Fig S1 c, d; S2 c, d and S3 c, d).

Stomatal conductance and net photosynthesis were measured on the second and the ninth day after the treatments' initiation. After two days, $\mathrm{Ca}^{2+} / \mathrm{Sr}^{2+}$ treatments did not affect stomatal conductance and net photosynthesis (Fig. 4a, b). On a ninth day, a significant reduction of both parameters was observed only in the group "+Sr" but not in the "-Ca/-Sr" (Fig. 4a, b). Moreover, a similar response was observed in Exp. 3 (Table 1.) while the decrease of both parameters during the ninth day was observed in the "-Ca/-Sr" group also (Fig S4).

The data obtained using the SEM coupled with EDS showed that the relative cell wall concentration of $\mathrm{Ca}^{2+}$ (in the groups not supplied with $\mathrm{Ca}^{2+}$ ) were $0.1-0.085 \%$, (Fig. 5), less than half of the concentration of the group supplied with $\mathrm{Ca}$ ("+Ca", $0.23 \%$ ). In groups that were not supplied with $\mathrm{Sr}^{2+}, \mathrm{no} \mathrm{Sr}^{2+}$ was detected. In the group " $+\mathrm{Sr}^{\text {", the relative }} \mathrm{Sr}^{2+}+\mathrm{Ca}^{2+"}$ concentration was not significantly different from the $\mathrm{Ca}^{2+}$ concentration in the group "+Ca". (" $+\mathrm{Sr}^{\prime}: \mathrm{Ca}^{2+}+\mathrm{Sr}^{2+}=0.212 \%$ while " $+\mathrm{Ca}^{2}: \mathrm{Ca}^{2+}=0.252 \%$ ).

\section{Diurnal uptake of $\mathrm{Ca}^{2+}$ and $\mathrm{Sr}^{2+}$}


In Exp. 5, water and nutrients uptake were measured every three hours. The diurnal pattern of water uptake was similar for both treatments ("+Ca" and " $\left.+\mathrm{Sr}^{\prime}\right)$ except for the midday peak that was moderately and significantly higher in the "Ca" group (Fig. 6a). The diurnal uptake rates of $\mathrm{Ca}^{2+}$ and $\mathrm{Sr}^{2+}$ were comparable, except at the beginning of the exposure, at 21:30h, when the $\mathrm{Sr}^{2+}$ uptake rate was significantly higher (Fig. 6b) (refer to Discussion, "The uptake rate and translocation pattern of $\mathrm{Ca}^{2+}$ and $\mathrm{Sr}^{2+}$ in tomato").

The cumulative uptake during the day was moderately and significantly higher in the " $+\mathrm{Ca}$ " compared to the " $+\mathrm{Sr}^{\prime}$ " while during the night, uptake rates were similar (Fig. 6c). Moreover, the day uptake rates of both $\mathrm{Ca}^{2+}$ and $\mathrm{Sr}^{2+}$ were twice as high as the night uptake rates (Day: $\mathrm{Ca}^{2+} 0.042 \mathrm{mmol} \mathrm{h}^{-1}, \mathrm{Sr}^{2+} 0.036 \mathrm{mmol}$ $\mathrm{h}^{-1}$; Night: $\mathrm{Ca}^{2+} 0.020 \mathrm{mmol} \mathrm{h}^{-1}, \mathrm{Sr}^{2+} 0.019 \mathrm{mmol} \mathrm{h}^{-1}$ excluding the first data point at 21:30 h) (Fig. $6 \mathrm{c}$ ).

\section{The effect of $\mathrm{Ca}^{2+}$ channel blockers on the uptake of $\mathrm{Ca}^{2+}$ and $\mathrm{Sr}^{2+}$}

In Exp. 6, when no blockers were applied, the uptake of $\mathrm{Ca}^{2+}$ and $\mathrm{Sr}^{2+}$ was similar (Fig. 7 "No blockers"). In the two groups treated with blockers (Fig. 7, "Lanthanum" and "Gadolinium"), the uptake of $\mathrm{Ca}^{2+}$ and $\mathrm{Sr}^{2+}$ was significantly lowered, showing a statistical difference compared to not treated plants (the $\mathrm{Ca}^{2+}$ and $\mathrm{Sr}^{2+}$ uptake halved). Moreover, in both groups treated with blockers, the uptake of $\mathrm{Ca}^{2+}$ was somewhat lower than $\mathrm{Sr}^{2+}$ but not significantly.

\section{Discussion}

$\mathrm{Ca}^{2+}$ is a major structural and regulatory plant nutrient whose function strongly determines and regulates the structural properties of plant cell walls (de Freitas et al. 2012a; Martins et al. 2018). The low mobility of $\mathrm{Ca}^{2+}$ in the phloem can lead to several nutritional disorders such as BER in tomato and pepper, internal rust in potato and bitter pit in apples (de Freitas et al. 2010; Palta 2010; de Freitas and Mitcham 2012; Hagassou et al. 2019; Mayorga-Gómez et al. 2020). Therefore, it is crucial to monitor and understand the factors governing the $\mathrm{Ca}^{2+}$ allocation within the plant, for which $\mathrm{Ca}^{2+} \mathrm{or} \mathrm{Sr}^{2+}$ stable isotopes are the most common tracer tool (Kalcsits et al. 2017; Song et al. 2018). The stable $\mathrm{Sr}^{2+}$ isotope $\left({ }^{88} \mathrm{Sr}\right.$ ) has many advantages: it is accessible, cheap, safe and simple to analyse (compared to radioisotopes). Here we demonstrated that in tomatoes, $\mathrm{Ca}^{2+}$ and $\mathrm{Sr}^{2+}$ uptake and allocation within the plant are comparable in the short-term (on a time scale between two to twenty hours), while in the long-term, nutrition with $\mathrm{Sr}^{2+}$ has detrimental effects starting from decreased transpiration to impaired biomass production. Nonetheless, we show that $\mathrm{Sr}^{2+}$ accumulates in a manner similar to $\mathrm{Ca}^{2+}$ in tomato plant tissues, specifically in tomato fruit cell walls, helping to prevent BER. 


\section{The uptake rate and translocation pattern of $\mathrm{Ca}^{2+}$ and $\mathrm{Sr}^{2+}$ in tomato}

Previous studies demonstrated that $\mathrm{Ca}^{2+}$ and $\mathrm{Sr}^{2+}$ behave similarly in the biosphere and that most plants cannot discriminate between them at their biospheric concentrations (Watanabe et al. 2007, 2016; Drouet and Herbauts 2008; Burger et al. 2019b). Therefore, $\mathrm{Sr}^{2+}$ has been used as a long- and short-term tracer of $\mathrm{Ca}^{2+}$ uptake and transport to all plant organs (Laszlo 1994; Storey and Leigh 2004; McGonigle and Grant 2015; Song et al. 2018; Rosen et al. 2019). However, data on comparing $\mathrm{Ca}^{2+}$ and $\mathrm{Sr}^{2+}$ uptake and translocation in tomato plants are scarce (Bowen H. J. M. and A. 1956; Seligmann et al. 2009), and to our knowledge, studies on using $\mathrm{Sr}^{2+}$ as a specific tracer of $\mathrm{Ca}^{2+}$ in tomato plants have not been done.

Our current study found that the diurnal uptake rate of $\mathrm{Sr}^{2+}$ and $\mathrm{Ca}^{2+}$ in the short-term experiments was comparable (Fig. $6 \mathrm{~b}$ and c) and that tomato plants do not distinguish between $\mathrm{Ca}^{2+}$ and $\mathrm{Sr}^{2+}$ in the shortterm. The results agree with an early hydroponic study which showed that tomato plants do not distinguish between $\mathrm{Ca}^{2+}$ and $\mathrm{Sr}^{2+}$ (Bowen H. J. M. and A. 1956).

Notably, at the first measuring point of the diurnal uptake dynamic (Fig. 6b, at 21:30h), the uptake rates of $\mathrm{Ca}^{2+}$ and $\mathrm{Sr}^{2+}$ were transiently significantly different, with the uptake rate of $\mathrm{Sr}^{2+}$ being much higher. This transient uptake increase might be because of the i) immediate and concentration-dependent effect of $\mathrm{Sr}^{2+}$ on the depolarisation of the root cell membrane (lasting for up to two hours and probably mediated by the voltage-dependent ion channels); ii) adsorption of $\mathrm{Sr}^{2+}$ onto root cell walls (Seligmann et al. 2009; Moyen and Roblin 2010; Moyen et al. 2011). The $\mathrm{Sr}^{2+}$ concentrations used (1-4 $\left.\mathrm{mM}\right)$ in all our experiments falls in the range of concentrations known to cause these effects (1-10 mM). Nevertheless, in long-term $\mathrm{Sr}^{2+}$ exposure experiments, tomato plants accumulated $\mathrm{Ca}^{2+}$ and $\mathrm{Sr}^{2+}$ at comparable rates (Fig. 3; Fig S 1-3), indicating that the differences in the uptake rates are transient.

\section{The $\mathrm{Ca}^{2+}$ and $\mathrm{Sr}^{2+}$ accumulation in tomato fruit cell wall}

The inability of many plants to distinguish between $\mathrm{Ca}^{2+}$ and $\mathrm{Sr}^{2+}$ has been shown in the literature (Watanabe et al. 2007, 2016; Drouet and Herbauts 2008), yet their transport and allocation within plant organs are not well described. In the current study, we showed that $\mathrm{Sr}^{2+}$ allocation to tomato fruit is comparable to $\mathrm{Ca}^{2+}$. Using EDS detector on fruit pericarp sections (Fig. 1), we showed that $\mathrm{Ca}^{2+}$ and $\mathrm{Sr}^{2+}$ accumulated in the same weight percentages in the fruit's cell walls, strongly suggesting that $\mathrm{Ca}^{2+}$ and $\mathrm{Sr}^{2+}$ share uptake and translocation pathways in tomato. The EDS results are congruent with the destructive mineral analysis (Fig. 3d). Moreover, previous studies support our observation on cell wall $\mathrm{Ca}^{2+}$ and $\mathrm{Sr}^{2+}$ allocation (Brambilla et al. 2002; Von Fircks et al. 2002; Burger and Lichtscheidl 2019). Specific co-localisation and comparable sink capacity of $\mathrm{Ca}^{2+}$ and $\mathrm{Sr}^{2+}$ in the "cell wall sac" of idioblasts in Morus alba L. has been shown by Katayama et al. (2013). The comparable uptake and allocation of $\mathrm{Sr}^{2+}$ and $\mathrm{Ca}^{2+}$ do not necessarily mean that $\mathrm{Sr}^{2+}$ can replace $\mathrm{Ca}^{2+}$ in its physiological roles. Here we 
report (to our knowledge, for the first time) that the application of $\mathrm{Sr}^{2+}$ strongly mitigated the development of BER to a level identical to $\mathrm{Ca}^{2+}$ (Fig. 3b and Fig. S2b).

The development of BER in tomato is multivariable but is always related to the fruit $\mathrm{Ca}^{2+}$ concentration, partitioning and distribution (Ho and White 2005; Hagassou et al. 2019), which in turn is strongly connected with the class of enzymes called "Pectin methylesterases" (PMEs). PMEs create $\mathrm{Ca}^{2+}$ binding sites in the cell wall and directly modify cell wall properties. De Freitas et al. (2012) have shown that the reduction in the activity of PMEs can directly determine $\mathrm{Ca}^{2+}$ partitioning and distribution in tomato fruits by reducing the amount of $\mathrm{Ca}^{2+}$ bound to the cell wall and decreasing BER development in tomato (more water-soluble apoplastic $\mathrm{Ca}^{2+}$ - less BER). Moreover, the work of Wu et al. (2018) and Anthon and Barrett (2006) supports the idea that stress (particularly heat stress) activates the PMEs, additionally depleting water-soluble apoplastic $\mathrm{Ca}^{2+}$, consequently leading to more pronounced stress symptoms. Our supposition is that $\mathrm{Sr}^{2+}$ can partly replace $\mathrm{Ca}^{2+}$ in the cell wall, competing with $\mathrm{Ca}^{2+}$ for $\mathrm{Ca}^{2+}$-binding sites, particularly during stress, leading to almost no change in the water-soluble apoplastic $\mathrm{Ca}^{2+}$, which in turn mitigates the development of BER. This hypothesis needs to be verified by further study.

\section{$\mathrm{Sr}^{2+}$ uptake pathway in tomato}

No specific $\mathrm{Sr}^{2+}$ transporters in plants have been reported to the best of our knowledge. Nevertheless, non-selective cation channels, which are pathways of $\mathrm{Ca}^{2+}$ uptake, can also be utilised by other cations, including Sr${ }^{2}$ (White and Broadley 2003; Kanter et al. 2010; Moyen and Roblin 2010; Demidchik et al. 2018). Lanthanum $\left(\mathrm{La}^{3+}\right)$ and gadolinium $\left(\mathrm{Gd}^{3+}\right)$ influence the $\mathrm{Ca}^{2+}$ uptake, at the level of the root cell membrane, by physically blocking the pore of non-selective cation channels and by competing with $\mathrm{Ca}^{2+}$ for the $\mathrm{Ca}^{2+}$-binding sites (Demidchik et al. 2002, 2018; Demidchik and Maathuis 2007; De Vriese et al. 2018). Using these blockers, we showed a comparable decrease in the uptake rate of both the $\mathrm{Ca}^{2+}$ and the $\mathrm{Sr}^{2}$ (Fig. 7), indicating that $\mathrm{Ca}^{2+}$ and $\mathrm{Sr}^{2+}$ share a part of the channel pathway in tomato plants. The uptake of elements was not completely suppressed, and a certain amount of $\mathrm{Ca}^{2+}$ and $\mathrm{Sr}^{2+}$ was uptaken by the plant (removed from the solution) (Fig. 7). There has been much debate in the last 20 years about the specific pathways of $\mathrm{Ca}^{2+}$ uptake into the roots and how it is transported into the xylem. Certain amount of evidence suggests that direct apoplastic uptake might play a substantial role in the process (White 2001; Thor 2019). Considering that $\mathrm{Ca}^{2+}$ and $\mathrm{Sr}^{2+}$ have been uptaken at the same rate, even in the presence of the blockers, it might be feasible that these two elements also share a possible root apoplastic uptake pathway; this hypothesis needs to be investigated further.

\section{$\mathrm{Sr}^{2+}$ toxicity in tomato, related to the duration of exposure}

Strontium toxicity to plants is well established (Burger and Lichtscheidl 2019), with toxic symptoms likely depending on the duration of exposure and concentration of $\mathrm{Sr}^{2+}$. This fact raises the following question, under which conditions can we utilise " $\mathrm{Sr}^{2+}$ as a tracer for $\mathrm{Ca}^{2+"}$ without experiencing the adverse, toxic effects? In a study on tomato seedling grown in agar medium for two weeks, $\mathrm{Sr}^{2+}$ toxicity leads to a 
significant reduction in shoot and root biomass at $\mathrm{Sr}^{2+}$ concertation of $4 \mathrm{mM}$ and above (Nagata 2019). Accordingly, in our current study, the addition of $\mathrm{Sr}^{2+}$ led to decreased stomatal conductance and net photosynthesis nine days after initiation of the treatments but not in the first $48 \mathrm{~h}$ of the application (Fig. 4 and Fig. S4). Minor, but a significant decrease in ET of $\mathrm{Sr}^{2+}$ treated plants was measured in midday only of the short-term hydroponic trial (Fig. 6). These results indicate that in short-term trials, at concentrations of 1-4 $\mathrm{mM}, \mathrm{Sr}^{2+}$ toxicity effects are minor and that $\mathrm{Sr}^{2+}$ is a reasonably reliable tracer. That does not hold for longer trials (over a few days). In the long-term experiments, the addition of $\mathrm{Sr}^{2+}$ had a significant adverse effect on the shoot biomass only in the experiments conducted in the summer (Exp. 2 and 3, Fig. 3, Fig. S1), indicating that the acceleration of $\mathrm{Sr}^{2+}$ accumulation with high illumination and temperature had probably led to a faster expression of the toxic effects (Kondo et al. 2003). These results are in accordance with Burger and Lichtscheidl (2019), which concluded that an increase in light intensity and temperature would drive the acceleration in $\mathrm{Sr}^{2+}$ uptake, while the $\mathrm{Sr}^{2+}$ accumulation will lead to phytotoxicity.

\section{Conclusion}

Our results indicate that in tomato plants, $\mathrm{Sr}^{2+}$ is comparable to $\mathrm{Ca}^{2+}$ in terms of uptake rate and, more importantly, in its distribution within plant organs, most notably tomato fruits. Using acknowledged $\mathrm{Ca}^{2+}$ blockers, we have shown that $\mathrm{Ca}^{2+}$ and $\mathrm{Sr}^{2+}$ most probably share similar molecular uptake pathway. Additionally, when $\mathrm{Sr}^{2+}$ is deposited in the fruit cell wall, it can partly substitute for $\mathrm{Ca}^{2+}$ and prevent $\mathrm{BER}$ formation.

Therefore, we conclude that $\mathrm{Sr}^{2+}$ can act as a reliable tracer for $\mathrm{Ca}^{2+}$ in short-term experiments conducted on different tomato organs. However, in the long-term studies, $\mathrm{Sr}^{2+}$ toxicity impairs photosynthesis and overall plant performance, slightly hindering its use as the reliable $\mathrm{Ca}^{2+}$ tracer. Furthermore, under conditions that stimulate growth, the establishment and manifestation of $\mathrm{Sr}^{2+}$ toxicity is expected to be faster.

The utilisation of $\mathrm{Sr}^{2+}$ as a tracer to study $\mathrm{Ca}^{2+}$ uptake and allocation can be used as an essential tool for understanding the environmental factors governing $\mathrm{Ca}^{2+}$ delivery to different plant organs, notably, fruit $\mathrm{Ca}^{2+}$ delivery. Such tools may support the development of new strategies aimed at mitigating fruit physiological disorders related to limited $\mathrm{Ca}^{2+}$ supply, affecting many fleshy fruit producers worldwide.

\section{Declarations}

\section{Funding}


The Ben-Gurion University of the Negev, through the scholarship received by Petar Jovanović, and the "Israeli vegetable board", partly funded the current research.

\section{Conflict of interest}

All authors certify that they have no affiliations with or involvement in any organisation or entity with any financial interest or non-financial interest in the subject matter or materials discussed in this manuscript.

\section{Availability of data and material}

The datasets generated during and/or analysed during the current study are available from the corresponding author on a reasonable request.

\section{Code availability}

Not relevant to the study.

\section{Authors' contributions}

Not declared.

\section{Ethics approval}

All authors declare that this article does not contain any studies with human participants or animals.

\section{Consent to participate}

Not relevant to the study

\section{Consent for publication}

All authors also declare that they have read the manuscript in full and approved the manuscript submission.

\section{Acknowledgements}

We thank Adi Bier Kushmaro, Yonatan Weizman and Natalie Toren for the technical assistance. We also thank Dr Moshe Halpern for the English language editing and Dr Asher Bar-Tal for the pre-review of our work. We are grateful to the Ben-Gurion University of the Negev and to the Israeli vegetable board for partially funding the research.

\section{References}

Åberg G, Jacks G, Wickman T, Hamilton PJ (1990) Strontium isotopes in trees as an indicator for calcium availability. Catena 17:1-11. https://doi.org/10.1016/0341-8162(90)90011-2 
Achary VMM, Parinandi NL, Panda BB (2013) Mutation Research / Genetic Toxicology and Environmental Mutagenesis Calcium channel blockers protect against aluminium-induced DNA damage and block adaptive response to genotoxic stress in plant cells. Mutat Res - Genet Toxicol Environ Mutagen 751:130-138. https://doi.org/10.1016/j.mrgentox.2012.12.008

Anthon GE, Barrett DM (2006) Characterization of the temperature activation of pectin methylesterase in green beans and tomatoes. J Agric Food Chem 54:204-211. https://doi.org/10.1021/jf051877q

Bowen HJM, A. DJ (1956) The Uptake of Calcium and Strontium by Plants from Soils and Nutrient Solutions. J Exp Bot 7:264-272. https://doi.org/http://www.jstor.org/stable/23686486

Brambilla M, Fortunati P, Carini F (2002) Foliar and root uptake of $134 \mathrm{Cs}, 85 \mathrm{Sr}$ and $65 \mathrm{Zn}$ in processing tomato plants (Lycopersicon esculentum Mill.). J Environ Radioact 60:351-363. https://doi.org/10.1016/S0265-931X(01)00109-6

Burger A, Lichtscheidl I (2019) Strontium in the environment: Review about reactions of plants towards stable and radioactive strontium isotopes. Sci Total Environ 653:1458-1512.

https://doi.org/10.1016/j.scitotenv.2018.10.312

Burger A, Weidinger M, Adlassnig W et al (2019a) Response of Plantago major to cesium and strontium in hydroponics: Absorption and effects on morphology, physiology and photosynthesis. Environ Pollut 254:113084. https://doi.org/10.1016/j.envpol.2019.113084

Burger A, Weidinger M, Adlassnig W et al (2019b) Response of Arabidopsis halleri to cesium and strontium in hydroponics: Extraction potential and effects on morphology and physiology. Ecotoxicol Environ Saf 184:109625. https://doi.org/10.1016/j.ecoenv.2019.109625

Capo RC, Stewart BW, Chadwick OA (1998) Strontium isotopes as tracers of earth surface processes: theory and methods. Geoderma 82:197-225

Coelho I, Castanheira I, Bordado JM et al (2017) Recent developments and trends in the application of strontium and its isotopes in biological related fields. TrAC - Trends Anal Chem 90:45-61. https://doi.org/10.1016/j.trac.2017.02.005

Dasch AA, Blum JD, Eagar C et al (2006) The relative uptake of $\mathrm{Ca}$ and Sr into tree foliage using a wholewatershed calcium addition. Biogeochemistry 80:21-41. https://doi.org/10.1007/s10533-005-6008-z

de Freitas ST, Amarante CVT d., Labavitch JM, Mitcham EJ (2010) Cellular approach to understand bitter pit development in apple fruit. Postharvest Biol Technol 57:6-13.

https://doi.org/10.1016/j.postharvbio.2010.02.006

de Freitas ST, Handa AK, Wu Q et al (2012a) Role of pectin methylesterases in cellular calcium distribution and blossom-end rot development in tomato fruit. Plant J 71:824-835. https://doi.org/10.1111/j.1365-313X.2012.05034.x 
de Freitas ST, Jiang CZ, Mitcham EJ (2012b) Mechanisms Involved in Calcium Deficiency Development in Tomato Fruit in Response to Gibberellins. J Plant Growth Regul 31:221-234.

https://doi.org/10.1007/s00344-011-9233-9

de Freitas ST, Mitcham EJ (2012) Factors involved in fruit calcium deficiency disorders. Hortic Rev (Am Soc Hortic Sci) 40:107-146. https://doi.org/10.1002/9781118351871.ch3

De Vriese K, Costa A, Beeckman T, Vanneste S (2018) Pharmacological strategies for manipulating plant Ca2 + signalling. Int J Mol Sci 19:. https://doi.org/10.3390/ijms19051506

Decreux A, Messiaen J (2005) Wall-associated kinase WAK1 interacts with cell wall pectins in a calciuminduced conformation. Plant Cell Physiol 46:268-278. https://doi.org/10.1093/pcp/pci026

Demidchik V, Davenport RJ, Tester M (2002) Nonselective cation channels in plants. Annu Rev Plant Biol 53:67-107. https://doi.org/10.1146/annurev.arplant.53.091901.161540

Demidchik V, Maathuis FJM (2007) Physiological roles of nonselective cation channels in plants: From salt stress to signalling and development. New Phytol 175:387-404. https://doi.org/10.1111/j.14698137.2007.02128.x

Demidchik V, Shabala S, Isayenkov S et al (2018) Calcium transport across plant membranes: mechanisms and functions. New Phytol 220:49-69. https://doi.org/10.1111/nph.15266

Drouet T, Herbauts J (2008) Evaluation of the mobility and discrimination of $\mathrm{Ca}$, Sr and $\mathrm{Ba}$ in forest ecosystems: Consequence on the use of alkaline-earth element ratios as tracers of Ca. Plant Soil 302:105-124. https://doi.org/10.1007/s11104-007-9459-2

Drouet T, Herbauts J, Gruber W, Demaiffe D (2005) Strontium isotope composition as a tracer of calcium sources in two forest ecosystems in Belgium. Geoderma 126:203-223.

https://doi.org/10.1016/j.geoderma.2004.09.010

Gerasopoulos D, Drogoudi PD (2005) Summer-pruning and preharvest calcium chloride sprays affect storability and low temperature breakdown incidence in kiwifruit. Postharvest Biol Technol 36:303-308. https://doi.org/10.1016/j.postharvbio.2005.01.005

Gilliham M, Dayod M, Hocking BJ et al (2011) Calcium delivery and storage in plant leaves: Exploring the link with water flow. J Exp Bot 62:2233-2250. https://doi.org/10.1093/jxb/err111

González-Fontes A, Navarro-Gochicoa MT, Ceacero CJ et al (2017) Understanding calcium transport and signaling, and its use efficiency in vascular plants. Elsevier Inc

Gould JM, Sternglass EJ, Sherman JD et al (2000) Strontium-90 in deciduous teeth as a factor in early childhood cancer. Int J Heal Serv 30:515-539. https://doi.org/10.2190/FTL4-HNG0-BELK-5EMH 
Hagassou D, Francia E, Ronga D, Buti M (2019) Blossom end-rot in tomato (Solanum lycopersicum L.): A multi-disciplinary overview of inducing factors and control strategies. Sci Hortic (Amsterdam) 249:49-58. https://doi.org/10.1016/j.scienta.2019.01.042

Ho LC, White PJ (2005) A cellular hypothesis for the induction of blossom-end rot in tomato fruit. Ann Bot 95:571-581. https://doi.org/10.1093/aob/mci065

Hocking B, Tyerman SD, Burton RA, Gilliham M (2016) Fruit Calcium: Transport and Physiology. Front Plant Sci 7:569. https://doi.org/10.3389/fpls.2016.00569

Kalcsits L, van der Heijden G, Reid M, Mullin K (2017) Calcium absorption during fruit development in 'honeycrisp' apple measured using 44ca as a stable isotope tracer. HortScience 52:1804-1809. https://doi.org/10.21273/HORTSCl12408-17

Kanter U, Hauser A, Michalke B et al (2010) Caesium and strontium accumulation in shoots of Arabidopsis thaliana: Genetic and physiological aspects. J Exp Bot 61:3995-4009.

https://doi.org/10.1093/jxb/erq213

Katayama H, Banba N, Sugimura Y et al (2013) Subcellular compartmentation of strontium and zinc in mulberry idioblasts in relation to phytoremediation potential. Environ Exp Bot 85:30-35.

https://doi.org/10.1016/j.envexpbot.2012.06.001

Kondo K, Kawabata H, Ueda S et al (2003) Distribution of aquatic plants and absorption of radionuclides by plants through the leaf surface in brackish Lake Obuchi, Japan, bordered by nuclear fuel cycle facilities. J Radioanal Nucl Chem 257:305-312. https://doi.org/10.1023/A:1024775511376

Kumar A, Singh UM, Manohar M, Gaur VS (2015) Calcium transport from source to sink: understanding the mechanism(s) of acquisition, translocation, and accumulation for crop biofortification. Acta Physiol Plant 37:. https://doi.org/10.1007/s11738-014-1722-6

Laszlo JA (1994) Changes in soybean fruit $\mathrm{Ca} 2+(\mathrm{Sr} 2+)$ and $\mathrm{K}+(\mathrm{Rb}+)$ transport ability during development. Plant Physiol 104:937-944. https://doi.org/10.1104/pp.104.3.937

Lide DR (2005) CRC Handbook ofChemistry and Physics, Internet Version. CRC Press, Boca Raton, FL, 2005

Marschner P (2011) Marschner's Mineral Nutrition of Higher Plants: Third Edition. Academic Press

Martins V, Garcia A, Costa C et al (2018) Calcium- and hormone-driven regulation of secondary metabolism and cell wall enzymes in grape berry cells. J Plant Physiol 231:57-67. https://doi.org/10.1016/j.jplph.2018.08.011

Mayorga-Gómez A, Nambeesan SU, Coolong T, Díaz-Pérez JC (2020) Temporal Relationship between Calcium and Fruit Growth and Development in Bell Pepper (Capsicum annuum L.). HortScience 55:906- 
McGonigle TP, Grant CA (2015) Variation in potassium and calcium uptake with time and root depth. Can J Plant Sci 95:771-777. https://doi.org/10.4141/cjps-2014-227

Miedema H, Bothwell JHF, Brownlee C, Davies JM (2001) Calcium uptake by plant cells-channels and pumps acting in concert. Trends Plant Sci 6:514-519. https://doi.org/10.1016/S1360-1385(01)02124-0

Miedema H, Demidchik V, Véry AA et al (2008) Two voltage-dependent calcium channels co-exist in the apical plasma membrane of Arabidopsis thaliana root hairs. New Phytol 179:378-385. https://doi.org/10.1111/j.1469-8137.2008.02465.x

Moyen C, Bonmort J, Roblin G (2011) Early Sr2+-induced effects on membrane potential, proton pumpingand ATP hydrolysis-activities of plasma membrane vesicles from maize root cells. Environ Exp Bot 70:289-296. https://doi.org/10.1016/j.envexpbot.2010.10.005

Moyen C, Roblin G (2010) Uptake and translocation of strontium in hydroponically grown maize plants, and subsequent effects on tissue ion content, growth and chlorophyll $\mathrm{a} / \mathrm{b}$ ratio: comparison with $\mathrm{Ca}$ effects. Environ Exp Bot 68:247-257. https://doi.org/10.1016/j.envexpbot.2009.12.004

Moyen C, Roblin G (2013) Occurrence of interactions between individual Sr2+- and Ca2+-effects on maize root and shoot growth and Sr2+, $\mathrm{Ca} 2+$ and $\mathrm{Mg} 2+$ contents, and membrane potential: Consequences on predicting Sr2+-impact. J Hazard Mater 260:770-779. https://doi.org/10.1016/j.jhazmat.2013.06.029

Nagata T (2019) Effect of strontium on the growth, ion balance, and suberin induction in solanum lycopersicum. Plant Root 13:9-14. https://doi.org/10.3117/plantroot.13.9

Palta JP (2010) Improving Potato Tuber Quality and Production by Targeted Calcium Nutrition: The Discovery of Tuber Roots Leading to a New Concept in Potato Nutrition. Potato Res 53:267-275. https://doi.org/10.1007/s11540-010-9163-0

Parvin K, Nahar K, Hasanuzzaman M et al (2019) Calcium-Mediated Growth Regulation and Abiotic Stress Tolerance in Plants

Peek S, Clementz MT (2012) Sr/Ca and Ba/Ca variations in environmental and biological sources: A survey of marine and terrestrial systems. Geochim Cosmochim Acta 95:36-52.

https://doi.org/10.1016/j.gca.2012.07.026

Pett-Ridge JC, Derry LA, Barrows JK (2009) Ca/Sr and87Sr/86Sr ratios as tracers of Ca and Sr cycling in the Rio Icacos watershed, Luquillo Mountains, Puerto Rico. Chem Geol 267:32-45.

https://doi.org/10.1016/j.chemgeo.2008.11.022

Pongrac $\mathrm{P}$, Vogel-Mikuš K, Regvar $\mathrm{M}$ et al (2013) On the distribution and evaluation of $\mathrm{Na}, \mathrm{Mg}$ and $\mathrm{Cl}$ in leaves of selected halophytes. Nucl Instruments Methods Phys Res Sect B Beam Interact with Mater 
Atoms 306:144-149. https://doi.org/10.1016/j.nimb.2012.12.057

Rosen C, Bierman P, Telias A et al (2019) Foliar Applied Strontium as a Tracer for Calcium Transport in Apple Trees. HortScience 39:853C - 853. https://doi.org/10.21273/hortsci.39.4.853c

Seligmann R, Wengrowicz U, Tirosh D et al (2009) Calcium translocation and whole plant transpiration: spatial and temporal measurements using radio-Strontium as tracer. In: International Plant Nutrition Collquium. Department of Plant Sciences, UC Davis. https://escholarship.org/uc/item/6fx7b4bg p

Seregin IV, Kozhevnikova AD (2004) Strontium transport, distribution, and toxic effects on maize seedling growth. Russ J Plant Physiol 51:215-221. https://doi.org/10.1023/B:RUPP.0000019217.89936.e7

Song WP, Chen W, Yi JW et al (2018) Ca distribution pattern in litchi fruit and pedicel and impact of Ca channel inhibitor, La3+. Front Plant Sci 8:1-11. https://doi.org/10.3389/fpls.2017.02228

Soudek P, Valenová Š, Vavř́ková Z, Vaněk T (2006) 137Cs and 90Sr uptake by sunflower cultivated under hydroponic conditions. J Environ Radioact 88:236-250. https://doi.org/10.1016/j.jenvrad.2006.02.005

Storey R, Leigh RA (2004) Processes modulating calcium distribution in citrus leaves. An investigation using x-ray microanalysis with strontium as a tracer. Plant Physiol 136:3838-3848. https://doi.org/10.1104/pp.104.045674

Tan J, Ben-Gal A, Shtein I et al (2020) Root structural plasticity enhances salt tolerance in mature olives. Environ Exp Bot 179:104224. https://doi.org/10.1016/j.envexpbot.2020.104224

Taylor MD, Locascio SJ (2004) Blossom-End Rot: A Calcium Deficiency. J Plant Nutr 27:123-139. https://doi.org/10.1081/PLN-120027551

Thor K (2019) Calcium-nutrient and messenger. Front Plant Sci 10:. https://doi.org/10.3389/fpls.2019.00440

Von Fircks Y, Rosén K, Sennerby-Forsse L (2002) Uptake and distribution of 137Cs and 90Sr in Salix viminalis plants. J Environ Radioact 63:1-14. https://doi.org/10.1016/S0265-931X(01)00131-X

Watanabe T, Broadley MR, Jansen S et al (2007) Evolutionary control of leaf element composition in plants: Rapid report. New Phytol 174:516-523. https://doi.org/10.1111/j.1469-8137.2007.02078.x

Watanabe T, Maejima E, Yoshimura T et al (2016) The ionomic study of vegetable crops. PLoS One 11:: https://doi.org/10.1371/journal.pone.0160273

White PJ (2001) The pathways of calcium movement to the xylem. J Exp Bot 52:891-899. https://doi.org/10.1093/jexbot/52.358.891

White PJ, Broadley MR (2003) Calcium in plants. Ann Bot 92:487-511. https://doi.org/10.1093/aob/mcg164 
Wu HC, Bulgakov VP, Jinn TL (2018) Pectin methylesterases: Cell wall remodeling proteins are required for plant response to heat stress. Front Plant Sci 871:1-21. https://doi.org/10.3389/fpls.2018.01612

\section{Figures}

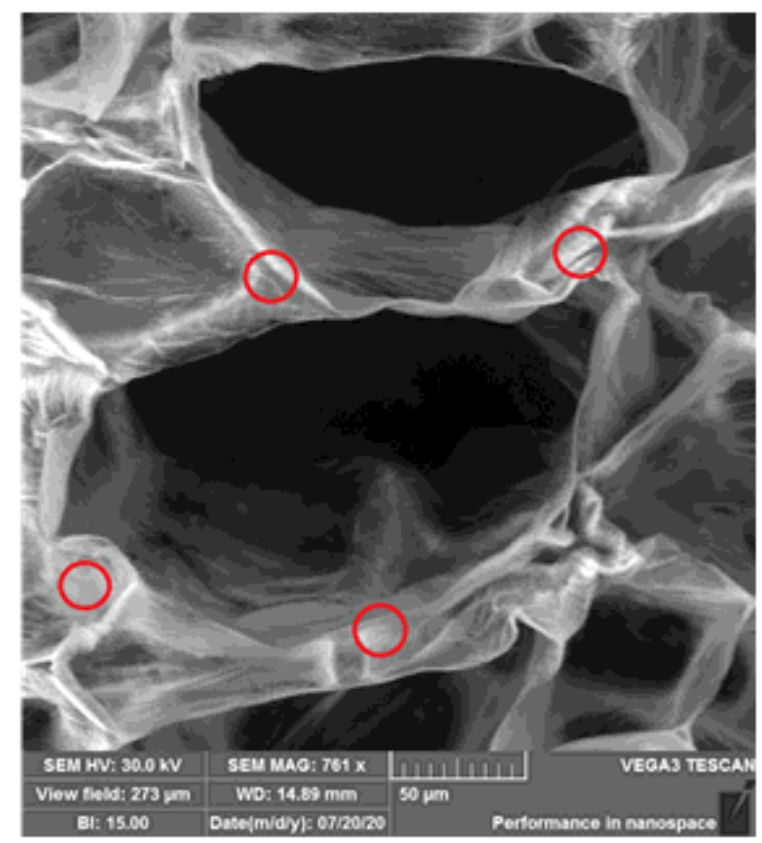

\section{Figure 1}

SEM microscope picture illustrating the scanning pattern

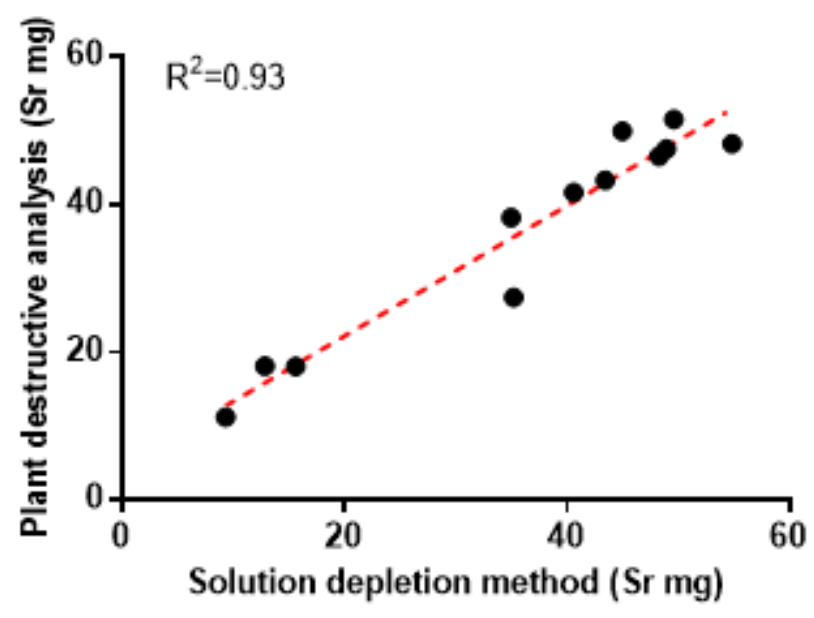

Figure 2

The agreement between the "solution depletion" method and destructive tissue analysis the correlation between $\mathrm{Sr} 2+$ uptake measured by the "solution depletion" method (mg plant-1) and plant destructive 
analysis following 20.5h exposure of tomato plants for to $4 \mathrm{mM} \mathrm{Sr2+} \mathrm{(Exp.} \mathrm{5).} \mathrm{Each} \mathrm{dot} \mathrm{represents} \mathrm{a}$ single plant $(p \leq 0.001)$

(a)

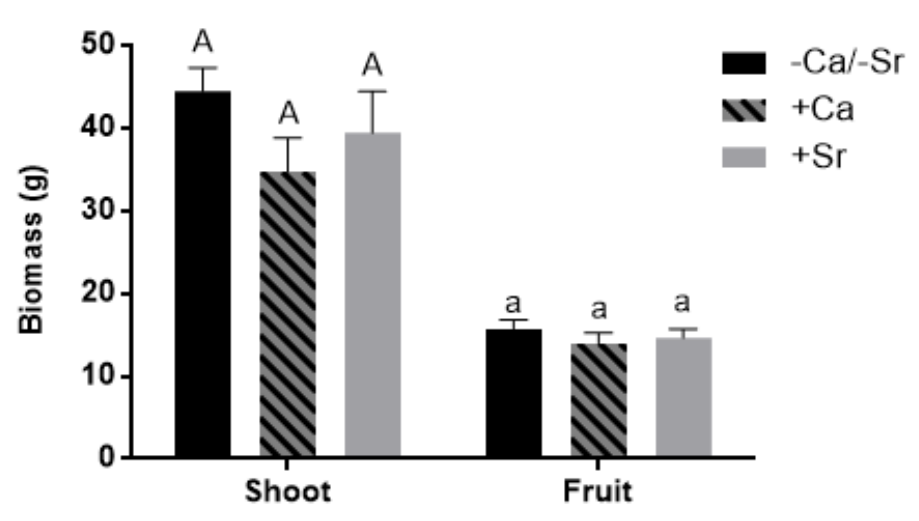

(c)

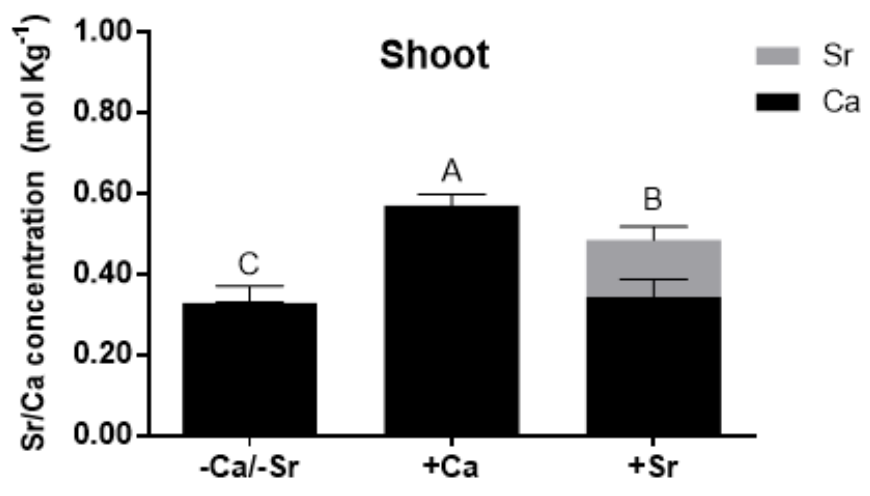

(b)

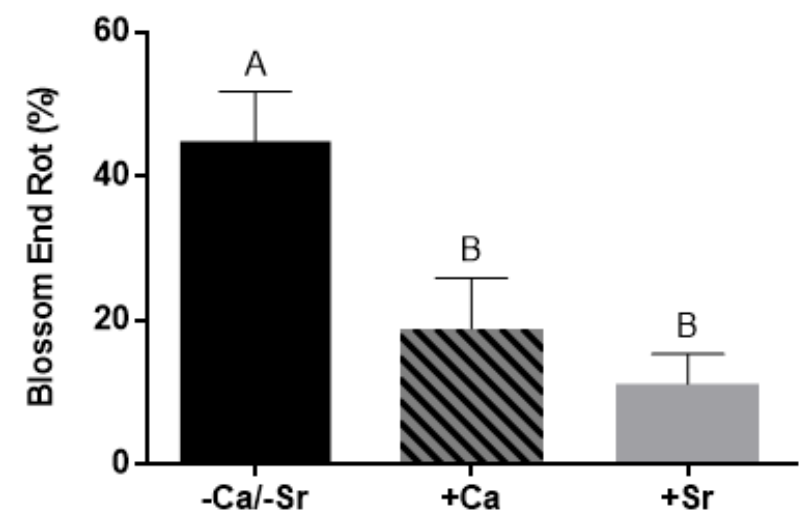

(d)

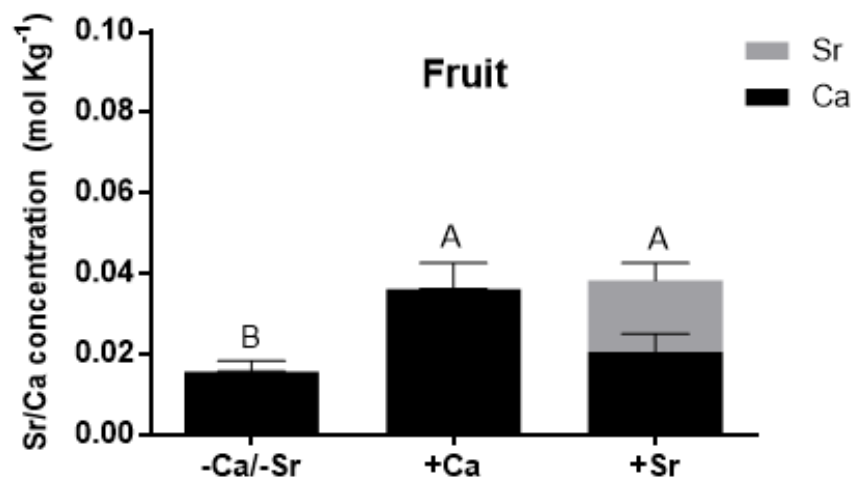

Figure 3

The response of tomato plants to long-term exposure to $4 \mathrm{mM} \mathrm{Ca} 2+, \mathrm{Sr} 2+$ or no $\mathrm{Ca} 2+$ and no $\mathrm{Sr} 2+$ (Exp.

4) (a) Shoot and fruit biomass, (b) Percentage of blossom end rot (BER), (c) Shoot and (d) Fruit Ca2+ and $\mathrm{Sr} 2+$ concentrations following 24 days of exposure to treatment with $4 \mathrm{mM} \mathrm{CaCl} 2(+\mathrm{Ca})$ or $4 \mathrm{mM} \mathrm{SrCl} 2$ $(+\mathrm{Sr})$ or the treatment that did not contain any of them (-Ca/-Sr) from December 2018 to January of 2019 (Exp. 4). Vertical bars indicate means $\pm S E, n=8$ for all treatments. On all panels, means indicated with the different letters are significantly different according to Tukey's HSD-test $(p \leq 0.05)$. Additionally, on the panels (c) and (d), in the group $+\mathrm{Sr}, \mathrm{Ca} 2+$ and $\mathrm{Sr} 2+$ concentrations have been added together and compared with two other groups 
(a)

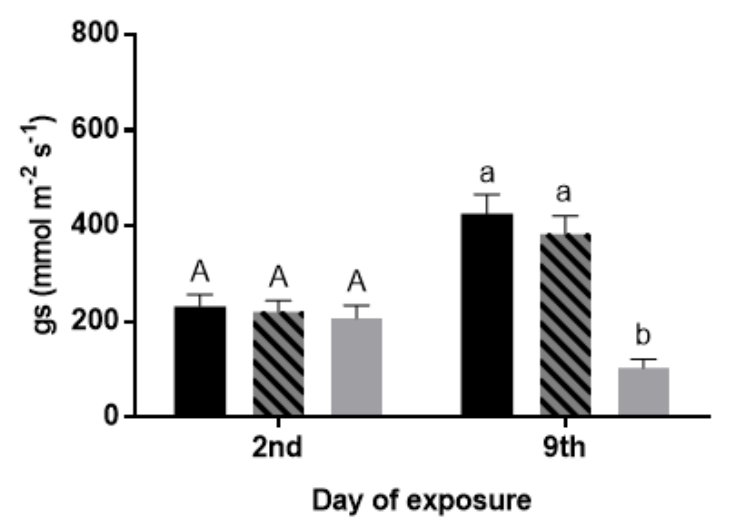

(b)

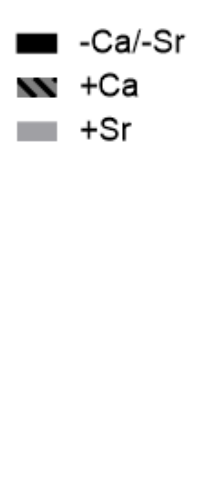

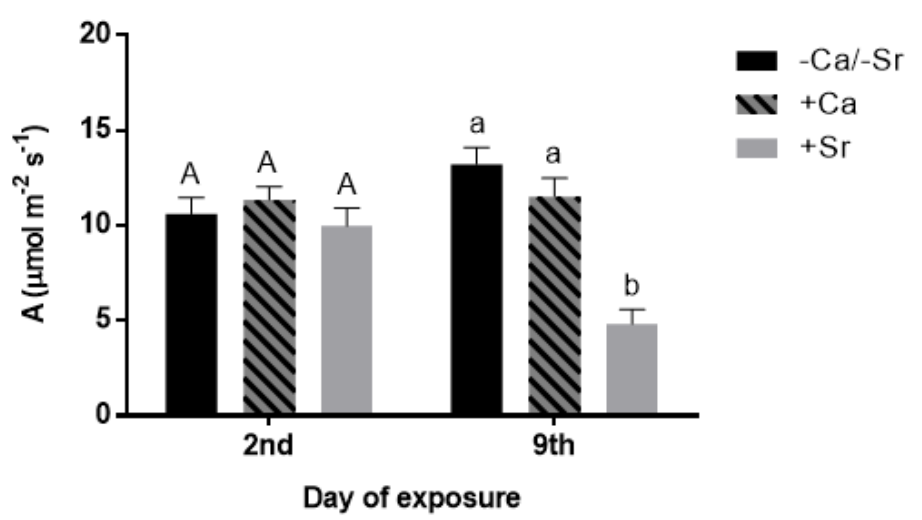

Figure 4

Stomatal conductance and photosynthetic rate following exposure to $4 \mathrm{mM}$ of $\mathrm{Ca} 2+$ or $\mathrm{Sr} 2+$ (a) Stomatal conductance (gs) and (b) net photosynthesis (A) on the second and the ninth day after the beginning of the treatment with $4 \mathrm{mM} \mathrm{CaCl} 2(+\mathrm{Ca})$ or $4 \mathrm{mM} \mathrm{SrCl} 2(+\mathrm{Sr})$ or the treatment that did not contain any of them (-Ca/-Sr) (Exp. 4). Vertical bars indicate means $\pm S E, n=5$ for all treatments. Means indicated with the different letters are significantly different according to Tukey's HSD-test $(p \leq 0.05)$

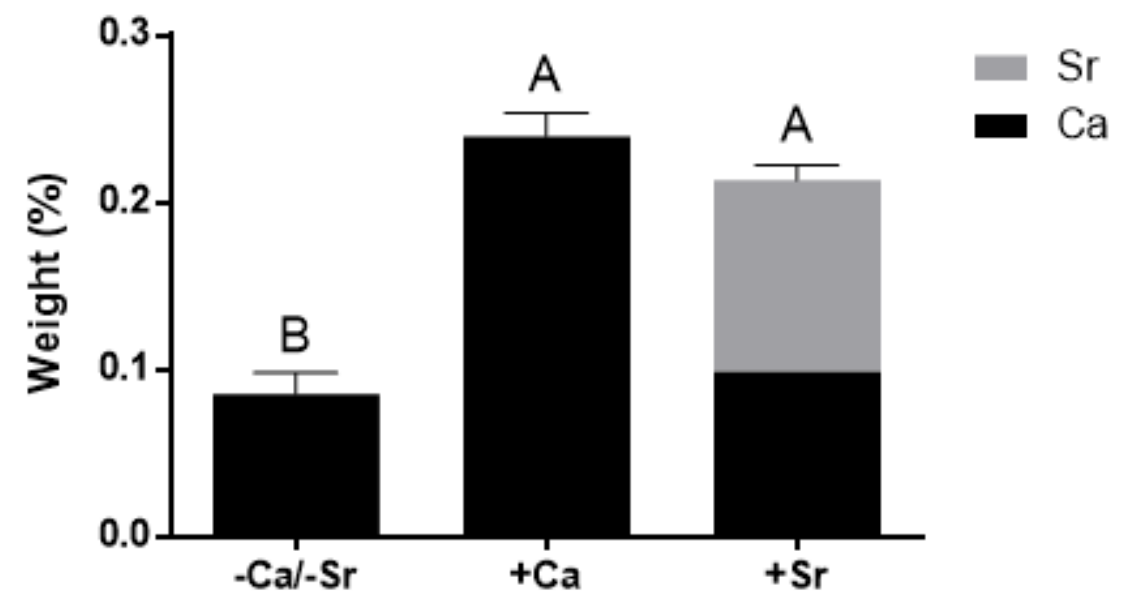

\section{Figure 5}

The relative concentration of $\mathrm{Ca} 2+$ and $\mathrm{Sr} 2+$ in tomato fruit cell wall detected by SEM-EDS Relative $\mathrm{Ca} 2+$ and $\mathrm{Sr} 2+$ concentration (weight \% of total analysed elements) in the fruit cell wall of plants treated with 4 $\mathrm{mM} \mathrm{CaCl} 2(+\mathrm{Ca})$ or $4 \mathrm{mM} \mathrm{SrCl} 2(+\mathrm{Sr})$ or the treatment that did not contain any of them (-Ca/-Sr) (Exp. 4). In the group $+\mathrm{Sr}, \mathrm{Ca} 2+$ and $\mathrm{Sr} 2+$ concentrations have been added together and compared with two other groups. Vertical bars indicate means $\pm S E, C a /-S r n=44,+C a n=39,+S r n=53$; Means indicated with the different letters are significantly different $(p \leq 0.05)$ according to the Tukey's HSD-test 
(a)

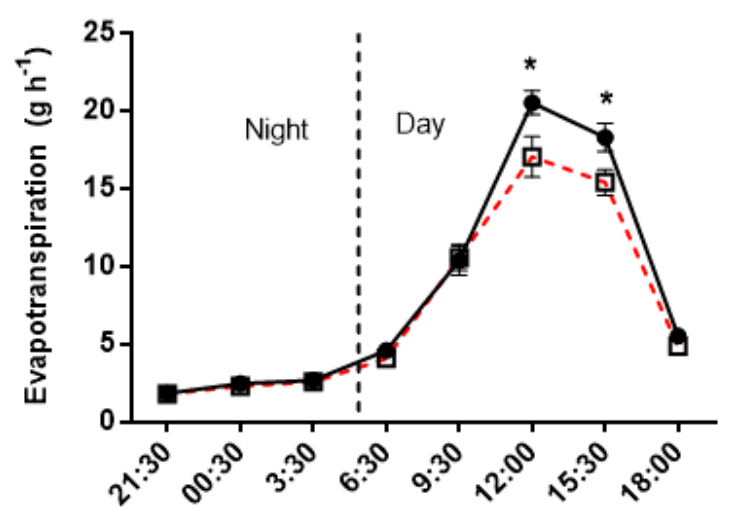

(b)

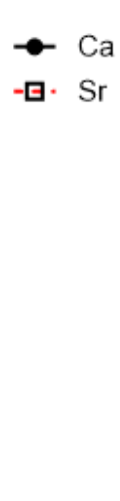

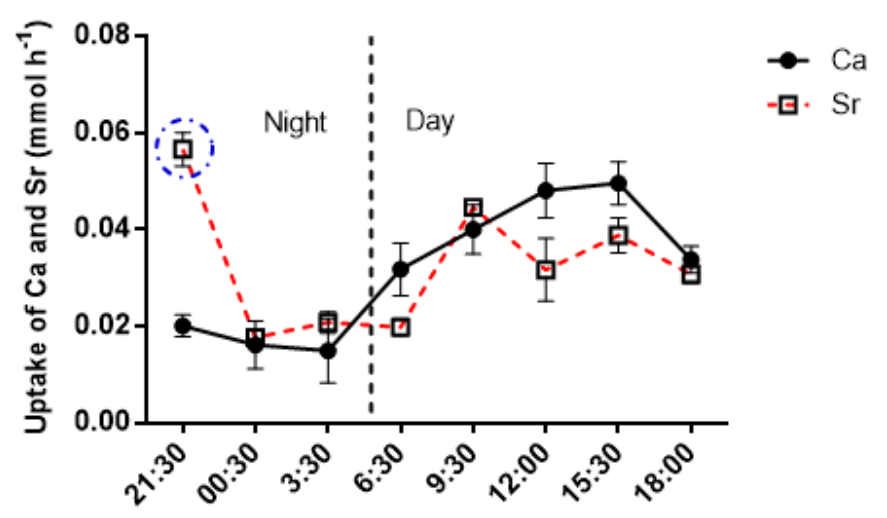

(c)

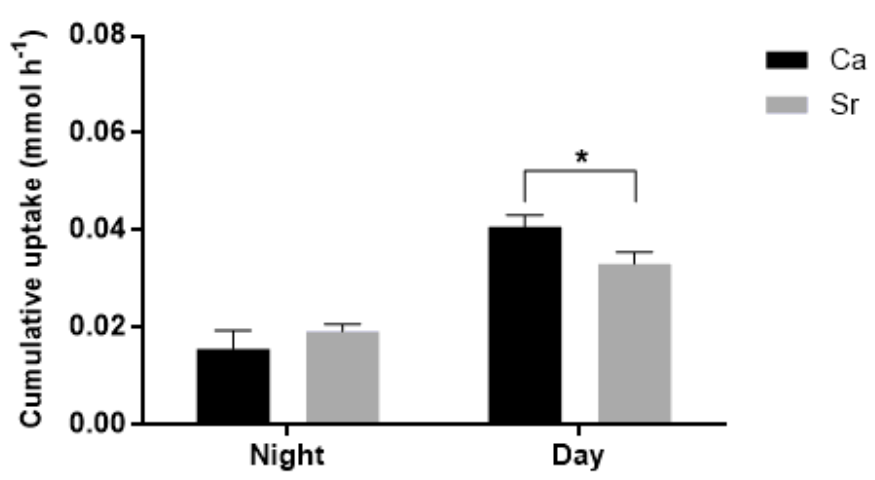

Figure 6

The diurnal dynamic of $\mathrm{Ca} 2+, \mathrm{Sr} 2+$ and water uptake in hydroponic conditions (a) diurnal evapotranspiration, (b) diurnal uptake dynamics of $\mathrm{Sr} 2+$ and $\mathrm{Ca} 2+$, (c) cumulative day and night uptake of $\mathrm{Sr} 2+$ and $\mathrm{Ca} 2+$. Vertical bars indicate $\pm \mathrm{SE}, \mathrm{n}=4$ for all treatments. Means marked with * are significantly different $(p \leq 0.05)$ according to Student's t-test

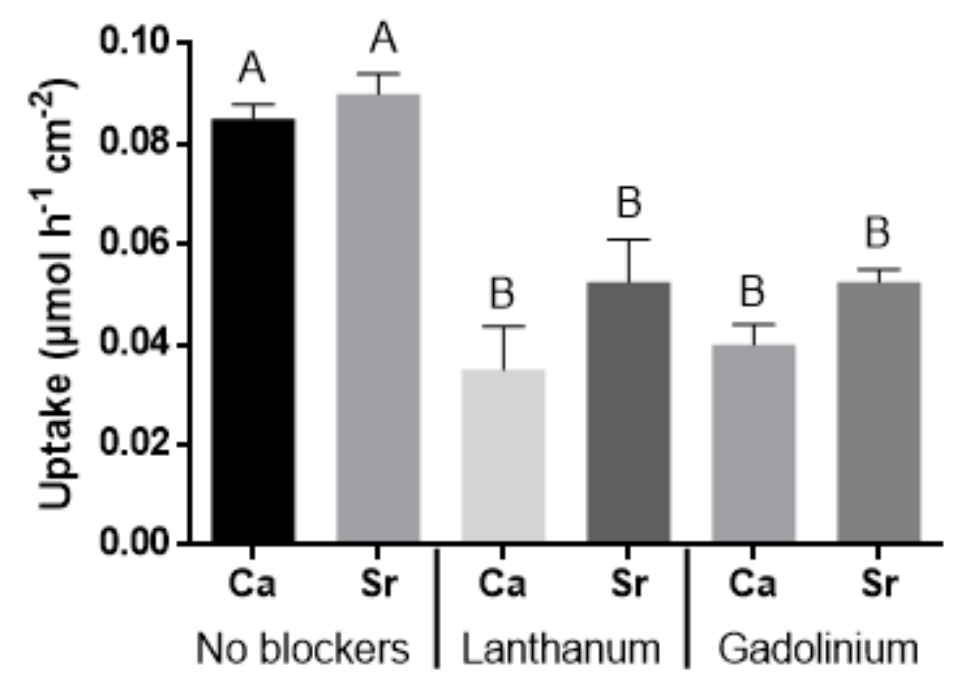




\section{Figure 7}

The effect of the $\mathrm{Ca} 2+$ channel blockers $\mathrm{LaCl} 3$ and $\mathrm{GdCl} 3$ on the uptake of $\mathrm{Ca} 2+$ and $\mathrm{Sr} 2+$ All the plants were exposed to both blockers in the concentration of $4 \mathrm{mM}$ for 4 hours. Vertical bars indicate means $\pm S E, n=4$ for all treatments. Means indicated with different letters are significantly different $(p \leq 0.05)$ according to Tukey's HSD-test

\section{Supplementary Files}

This is a list of supplementary files associated with this preprint. Click to download.

- Supplementaryinformation.docx 